LSP International Journal, Vol. 7, Issue 2, 2020, 19-36

(C) Universiti Teknologi Malaysia

E-ISSN 2601-002X

DOI: https://doi.org/10.11113/lspi.v7.16310

\title{
Role Play Activities: An Innovative Approach to Teaching Speaking Skills in an ESL Classroom
}

\author{
Nurhamimi Togimin \\ School of Education, Faculty of Social Sciences and Humanities, Universiti Teknologi Malaysia, 81310 UTM \\ Johor Bahru, Johor, Malaysia \\ Haliza Jaafar* \\ Language Academy, Faculty of Social Sciences and Humanities, Universiti Teknologi Malaysia, 81310 UTM \\ Johor Bahru, Johor, Malaysia
}

Submitted: 17/08/2019. Revised edition: 26/11/2020. Accepted: 26/11/2020. Published online: 30/11/2020

\begin{abstract}
Encouraging students to speak during classroom activities is an effective strategy to improve their acquisition of the target language. Activities related to real life situation such as role play, debate and simulation provide substantial rehearsal and practice and they allow students to not just learn phrases, but also learn how to communicate in various circumstances. Recent studies have revealed that students who are exposed to learning using role play activities improve significantly in speaking competency. Hence, the aim of this study is to investigate how role play activities in an ESL classroom can be an innovative approach in improving students' speaking skill. A total of nine undergraduate students from the Faculty of Computing in a public university in the Southern region of Malaysia were involved in this study. The main purpose for choosing the students as participants of the study was due to their low English proficiency based on their MUET results. The instruments used in this study were observation checklist and questionnaire. All the findings were tabulated and analysed qualitatively (observation checklist) as well as quantitatively (questionnaire). From the analysis carried out, it was evident that the students made positive improvement particularly in fluency, comprehension, context, and interactive communication. Besides that, the students felt that role play activities had brought positive effects on their English-speaking skills as obtained from the results of the questionnaire. Thus, it can be deduced that role play activities do have positive effects on students' English-speaking skills.
\end{abstract}

Keywords: Role play activities, English speaking skills, ESL, fluency, comprehension, context, interactive communication

\subsection{INTRODUCTION}

Language learners and ESL instructors should realise that there is usually more than one possible route to any communication goal and the success can depend as much on knowing how to approach a problem as on knowing what to say. In conversation, 'difficult' input may be made comprehensible through the mutual efforts of the 'participants' to make appropriate adjustments to the interactions. Skills especially in listening and speaking, in making such adjustments, forms part

*Correspondence to: Haliza Jaafar (email: haliza@utm.my) 
of strategic competence in the language. Sadly, ESL classrooms mostly focus on the writing and reading skills because that would be the easiest skills to monitor. Bygate (1987) and Rao (2019), however, asserted that speaking deserves more focus because it is useful in students' present and future lives. The ability to speak and listen is fundamental to students' language and social development as talk underpins learning and thinking. It is vital that its significance is recognised by students, parents and teachers. Students need to be provided with many and varied contexts for talk, but they also need direct teaching in the skills of speaking and listening. Therefore, it is necessary for students to learn how to speak English and an ESL classroom has long become a major platform for developing students' speaking skills. Teachers and educators apply various teaching strategies to facilitate students' acquisition of the speaking skills, for example, through role-play activities.

Getting students to speak during classroom activities is one good strategy to have them learn the target language. Seliger (1977) and De Wilde et al. (2020) argued that students who create substantially more language input from stimuli inside and outside of the formal classroom context are more proficient than students who do not look for chances to be exposed to the target language input. Thus, activity such as role playing can expose students to the target language by giving them input in the form of key cards as guidance. Teacher can create classroom activities that allow students thousands of opportunities to speak the target language by providing collaborative tasks and shared knowledge. For instance, role play can definitely improve students' speaking competence because through it, students can experience real speech that are commonly used in real day-to-day situation in an ESL classroom. These activities provide substantial rehearsal and practice, and they allow students to not just learn phrases, but also learn how to communicate in various circumstances (Porter-Ladousse, 1987). A recent study by Rayhan (2014) revealed that students who are exposed to learning using role play activities significantly improved their speaking competency. It is observed that as respondents become more engaged in the lesson; they negotiate with and assist each other during role play activities, and thus, improving their speaking and communication skills.

\subsection{BACKGROUND OF STUDY}

Classroom tasks differ in the linguistic and strategic demands they make of learners or students. Those that require two-way information exchange result in more interactional adjustment (Doughty and Pica, 1986), and role play is one example of a two-way information exchange. It is one of the many interesting and creative English teaching strategies that can be implemented in an ESL classroom to help improve students' speaking skills. Scrivener (2005) defined role play as:

"In role play, students are usually given some information about a character (e.g. a person or a job position). These are often written on role cards. Students do a little preparation and after that cooperate with other students to act out small scenes using their own ideas, as well as any ideas and information from the role cards. A role card could be supplying the name of the role e.g. 
mother, seller or offering guidance as to what to do rather than the role itself, e.g. buy a train ticket to London" (Scrivener, 2005, p. 155).

In role play, role cards are given to provide information to students about their roles or characters. Scrivener (2005) added that a good set of role cards provides a great deal of various viewpoints and sharp disagreements. Students also require an ample amount of time to prepare appropriate language and ideas before acting out in front of the classroom. At this particular level, students do not only use the information provided in the role cards, but they also apply and add their prior knowledge to generate innovative ideas.

In addition, role play is a suitable speaking activity that gives students clues of various situations through activities adapted from real life situations. Qing defined role play as the projection of real life situations into social activities while Ments (1999) interpreted it as a platform where every player is part of the social surrounding of the others and they evaluate their repertoire of behaviours or experiment the communicative behaviour of the group.

Thus, when students are required to role play, they have to think of the proper language to be used to express themselves and communicate with other players. This encourages them to acquire oral competence and simultaneously gears up their self-esteem. Role play gives opportunities to students to pretend to be someone else. Such a technique may assist timid students to overcome their shyness of speaking. Shy students often have difficulty talking about their experiences or about themselves. The fact that they are someone else makes them feel that their own identity is not implicated (PorterLadousse, 1987). As speaking skills need substantial exposure and practice, role play can be a good platform in an ESL classroom. It also helps students to adopt the appropriate moods and verbal expression of the provided context, which they then act out during the performance stage. For instance, when they are instructed to act out the role of a bank officer and a client, they are introduced to a context which is novel and challenging to them. This provides them with opportunities to self-discover their creativity and to look for different language, emotion, expression and environment. As students do preparation, they regain their self-confidence and acquire competence in the target language.

Role play is an interactive teaching method which provides creativity and innovation in the way a particular classroom is conducted. The teacher has to be aware of the students' ability to decide on the most appropriate topic to be carried out in the activities. Role play is an effective method which pays particular attention to the speaking in the target language. Maxwell (1997) claimed that role play can result in students' improvement in speaking skills. It can assist students to improve their second language. Under the same note, Richards and Rodgers (2001) defined role play as an activity which can develop students' interpersonal and social relationship. Similarly, Chen Jun (2006) proposed that role play can provide the students a wide range of opportunities to practice the real speech in the classroom.

Hall, Quinn, and Gollnick (2008) hypothesized that role play can help develop learners' fluency particularly in speaking skills. The broad range of language functions such as apologizing, greeting and enquiring is taught and exercised in this activity. The students focus more on the meaning rather than the form of the language. Therefore, through role play teachers can train the students' speaking skills in any social situations (Porter-Ladousse 1987). 
Therefore, role play is indeed effective in teaching speaking skills as it provides students opportunity to practice speaking in various social settings and roles. Furthermore, role play is suitable to be implemented in an ESL classroom to overcome the problem of low speaking proficiency among students because this method is learner-centred and stresses on interactions in real life situations (Sumpana, 2010). In fact, human communication is not restricted to only one particular setting and role play is beneficial enough to provide students with opportunities to act out and practice different communicative settings.

This study aims to investigate the effects of role play activities on students' speaking skills whereby the researcher designed several situations which were imitates real life contexts and the respondents had to assume certain roles and act the situations out in front. So, the respondents had to prepare and create their own appropriate language in order to build interpersonal relationship during the role play activities. Thus, the studies carried out by previous researchers cannot be further from the reality when comparing it to the Malaysian ESL classroom whereby the apparently comparable situation can be seen concerning the common crisis of ESL students' degrading speaking skills. As suggested by Yahaya (2011), there is a crucial need to improve the level of English competency among Malaysian students. Therefore, objective of this study is to investigate the effects of role play activities on students' speaking skills in an ESL classroom.

\section{$1.3 \quad$ METHODOLOGY}

This study was carried out to examine in what way role play activities in an ESL classroom have an impact on student's speaking skills. A mixed method was selected as the research design for this study as it amplifies the strength of the study and provides valid answer for the research question beyond the limitation of a single method (Christine, 2004). Qualitative data was collected through observations while quantitative data was collected through questionnaire. The observation checklist served the purpose of identifying students' level of speaking skills during pre-test and post-test sessions. It was divided into four different components analysing students' speaking ability which were:

i) Fluency, containing three items which looked at students' ability to speak fluently during role play activities,

ii) Comprehension, containing an item that observed students' ability to generate idea through input (key cards) given at the beginning of speaking activities,

iii) Context, containing five items that looked at students' ability to perform oral communication according to the given setting and situation, and

iv) Interactive Communication, containing three items that looked at students' ability to maintain and keep up communication during role play activities. 
The questionnaire consists of two sections. The first section contains socio-demographic questions such as gender, ethnicity and the students' MUET results. All of these components were constructed to help the researcher to understand the students' backgrounds better. The second section of the questionnaire was constructed to help the researcher examined the effects of role play activities towards the students' English-speaking skills. There were 10 structured questions in the form of a four-point Likert scale in which the students were required to choose from 'Strongly Disagree', 'Disagree', 'Agree' and 'Strongly Agree' to best reflect how they felt about the statement.

In this study, purposive sampling was used to select students with low level English proficiency as the sample. The proficiency level was determined via the Malaysian University English Test (MUET) results. A total of nine (8 males and 1 female) first-year students from the Faculty of Computing in this study were chosen to participate in this study. The students' individual MUET achievements are as shown in Table 1.1.

Table 1.1 Students' MUET individual achievements

\begin{tabular}{|l|l|}
\hline Student & Band \\
\hline Student 1 & 2 \\
\hline Student 2 & 3 \\
\hline Student 3 & 2 \\
\hline Student 4 & 2 \\
\hline Student 5 & 2 \\
\hline Student 6 & 3 \\
\hline Student 7 & 3 \\
\hline Student 8 & 2 \\
\hline Student 9 & 2 \\
\hline
\end{tabular}

The students were divided into groups of 3 and given a test which to identify their level of Englishspeaking skills. The pre-test role play activity was adapted by the researcher from MUET Speaking Test. The topic given was 'Road Accident' and was set with a specific situation as well as roles which were 'motorcyclist', 'witness' and 'doctor'. Each group was given 25 minutes to prepare their script and story flow and another 10 minutes to perform the role play according to the given situation and roles. The students were also given key cards to give them ideas on how to conduct the role plays. 
During performing, the students were observed of their English-speaking skills according to an observation checklist.

After conducting the pre-test, the researcher provided a four-week treatment for the students by employing role play activities. The students were divided into three groups and each group received a task sheet containing a role play topic, a setting, a situation as well as roles for them to act out. Then, the researcher briefed the students on what they were supposed to do according to the task instruction and key cards were given to provide ideas on how to conduct the role plays. After that, the students were given 25 minutes to prepare and another 10 minutes to perform the role play according to the given situation and roles. During performing, the students were observed of their English-speaking skills according to an observation checklist and notes were taken down on the students' performance both for referencing purpose. After all groups had carried out their role plays, the researcher provided feedback as input for the students to reflect and improve their role-playing skills and speaking performance. The same exact procedures were used in Treatments 2,3 and 4 with different topics, settings, situations and roles.

In the post-test, the researcher provided the students with a test which served the purpose of examining the difference in the students' level of English-speaking skills prior to the treatment and after the treatment was given. The post-test which consists of a role play activity was adapted from MUET Speaking Test. It covered the topic 'Social Service' and was set with a specific situation as well as roles which were 'elderlies' and 'caretaker'. Following the same procedures as in the pre-test, the students were divided into 3 groups and given 25 minutes to prepare and another 10 minutes to perform the role play according to the given situation and roles. The students were given key cards to give them ideas on how to conduct the role plays. During performing, the students were observed of their English-speaking skills according to an observation checklist as used in the pre-test.

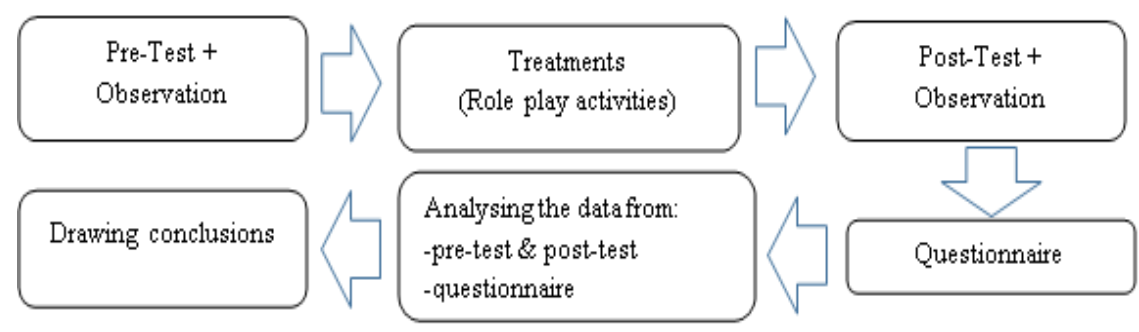

Figure 1.1 Data collection procedure

For the pre-test and the post-test, a qualitative analysis was made since qualitative method was used to identify significant differences in the level of the students' English-speaking skills in aspects of fluency, comprehension, context and interactive communication found during the pre-test and the post-test according to the observation checklist. 
For the questionnaire, the analysis was performed using a quantitative approach. Descriptive statistics were used to explore the effects of role play activities on the students' English-speaking skills. The score was accumulated to help identify whether the role play activities have effects on the students' English-speaking skills or not.

\subsection{RESULT AND DISCUSSION}

The following sections will discuss in detail the analysis conducted and the findings obtained.

\subsubsection{Observation Checklist: Analysis of the Students' English-Speaking Skills}

\subsubsection{Analysis of Students' Fluency}

Table 1.2 Observation checklist on students' fluency

\begin{tabular}{cccc}
\hline No. & Item & $\begin{array}{c}\text { Pretest } \\
\text { (No. of } \\
\text { students) }\end{array}$ & $\begin{array}{c}\text { Post-test } \\
\text { (No. of } \\
\text { students) }\end{array}$ \\
\hline 1 & Able to use pauses effectively during the role play & 3 & 8 \\
2 & Do not say "um" and "ah" too much in the & 2 & 6 \\
3 & Able to speak loud enough during the role play & 5 & 9 \\
& (e.g.: no hands covering mouth when speaking) & & \\
\hline
\end{tabular}

Item 1 in Table 1.2 shows that eight students were able to use pauses effectively during the role play in the post-test as compared to only three students in the pre-test. In the pre-test, it was seen that Student 3 talked continuously without stopping at appropriate pauses. He was unable to arrange his flowing ideas properly causing him to mix up ideas in one long, non-stopping, mixing sentence. For example,

S3: okay okay, in, out, in and <PULLS S2 LEG> [S2: ughh!] out, nice, okay. umm, okay, I think the bone just umm in, okay ahh ahh your leg will be simen [SIC] maybe in 1 or 2 months, we will have this simen [SIC] leg, ah but you have to come to hospital weekly because we want to see you and tell your bone, clear or not. understand?

We can see from the example that Student 3 spoke of different topics in one long sentence without pausing appropriately when necessary. Apparently, he talked of two different things; about the bone has just been 'in' and the casting of the leg of another student, in one sentence without addressing a tone signifying a pause. In the post-test however, almost all the students managed to use pauses 
effectively during speaking. They could organise their ideas and deliver every one of them clearly during the role play. For example,

S2: umm, I'm [SIC] actually a former truck driver [S9: oh, truck driver] mmm, used to be a truck driver for a company. However, the company fired me a long time ago

S9: why they fired you?

S2: actually, because I was involved in an accident, quite, quite big accident. and because of that accident I wasn't able to mmm, to become a truck driver anymore. I terribly injured in that accident.

Student 2 was able to depict the chronology of his past life of being a truck driver and how he got involved in a terrible accident and then the consequences of that accident which made him unable to become a truck driver anymore. He told his stories to other speakers clearly, in an orderly manner by pausing at appropriate places, making other speakers able to understand what he was saying. He uttered different topics in different sentences and did not mix up sentences. This positive effect of role-play on the students of being able to use pauses effectively can be further supported in the questionnaire with 100\% of the students (67\% 'Agree' and 33\% 'Strongly Agree') agreed that role play helped improve their English-speaking skills. It is apparent that the students were able to see for themselves of the beneficial effect that role play activities had on their English-speaking skills.

Item 2 shows that 6 students were able to not say "um" and "ah" too much in the speaking during the role play in the post-test as compared to only 2 students in the pre-test. In the pre-test, it was observable that Student 2 used a lot of "fillers' like "mmm" and "aaa" in his speaking which signified his lost for words to say during the role play. He needed time to think what to speak and thus filled his sentence with these 'fillers'. This is evident in the extract below:

S2: hello? aaa hello yeah emm there's a man who aaa being hit by a car and mmm yeah [S1: my leg ughh my leg] can you come here? okay okay <PATTING SI> calm down bro calm down, I think you'll be okay.

We can see that Student 2 used fillers in only one sentence more than three times which indicates that he was unable to find the right words to say at that particular point of conversation. As a result, he automatically used a lot of fillers to fill the gap in his speech; and fillers usually occur in natural speech when gaps or hesitations appear during the production of sentences (Santos, 2016, Lucky Rahayu Nurjamin et al. 2020).

Contrary to the above, in the post-test, several students were able to produce sentences in the role play without using too much fillers. They were able to manifest their ideas into speaking without much difficulty and hardship. For an instance,

S8: okay mmm ahh I was assigned by my company to ask a few questions to both of you

S7: okay 
S8: so ahh may I know what, what is [SIC] your first impression towards me when I first come [SIC] here because this is my first day. so, may I know what's your first impression towards me?

We can see from the extract above how Student 8 managed to speak her sentences smoothly without any interruption from fillers. This is another positive effect of role play that can be supported by the respondents with $67 \%$ of the students (45\% 'Agree' and 22\% 'Strongly Agree') agreed that they were able to express their ideas clearly through role play. Having role plays as activities in the classroom trained the students to express themselves and speak their mind as broad as possible. Role plays also get the students familiar with a variety of situations when they perform simulations of reallife events as practice. Kusnierek (2015) highlighted in her study of role play activities on ESL students that such activities are expressive in nature and able to provide sufficient practice to students of possible situations or events that they might likely encounter in life.

Item 3 shows that all nine students were able to speak loud enough during the role play in the post-test as compared to only five students in the pre-test. In the pre-test, some students were seen left out when performing role play as a result of not being accustomed to speaking English loudly and clearly in front of their classmates. They seemed uncomfortable when acting out and consequently, they did not speak loud and clear when uttering their dialogues. For example,

S9: I know. ahh so, ahh as you can see here, we will look at here, we have ahh while you are [SIC] fain...ting, ahh we have done some $x$ ray and CT scan. so, as you can see here, you have broken your arms and your leg. and ahh so ahh, we examine [SIC] your $x$ ray and CT scan, you have a tumour

Student 9 covered his mouth with a paper in his hand when uttering the word 'fainting'. He apparently was not sure of saying the word 'fainting' in his speech and consequently just blurted the word out. Just he was conscious of his uncertainness of the word 'fainting', his voice faded and covered his mouth with the paper he was holding in his hand.

However, in the post-test, all the nine students managed to deliver their dialogues loudly and clearly and was able to listen and speak to each other clearly and manifest their ideas into their speech. As a result, they were all able to achieve mutual understanding when speaking to each other during the role play. For an instance,

S7: why is it so loud? [S5: oh my god!] are you deaf?

S5: <SHOCKED> oh, oh why you don't knock the door?

S7: I already knock [SIC] the door but you cannot hear

S5: I was getting my mood on this jam, you know 


\subsubsection{Analysis on Students' Comprehension}

Table 1.3 Observation checklist on students' comprehension

\begin{tabular}{cccc}
\hline No. & Item & $\begin{array}{c}\text { Pretest } \\
\text { (No. of } \\
\text { students) }\end{array}$ & $\begin{array}{c}\text { Post-test } \\
\text { (No. of } \\
\text { students) }\end{array}$ \\
\hline 1 & $\begin{array}{c}\text { Able to follow cues provided in the } \\
\text { key cards }\end{array}$ & 3 & 9 \\
\hline
\end{tabular}

The item in Table 1.3 shows that seven students could follow the cues provided in the key cards during the role play in the post-test as compared to only three students in the pre-test. In the pre-test, Student 7,8 and 9 was out of topic when they did not follow the situation, setting and roles given for conducting the role play. Before the pre-test, all the students were given a clear instruction on how to conduct the assigned role play. They were briefed that each student would have to take up one role and they would have to simulate a specific situation. However, during the pre-test role play, the students changed the roles given when the doctor [Student 9 was found guilty of hitting the motorcyclist (Student 7) evidenced by the video recorded by the witness (Student 8)]. They apparently did not stick to the roles chosen earlier and as a result, changed the flow of the whole story and combined a lot of non-related topics in one specific setting. The following is an example.

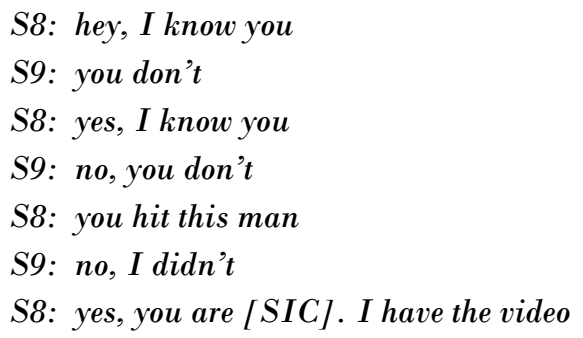

From the extract above, it is clear that the role of the doctor changed once he was found guilty of hitting the motorcyclist and causing the terrible injury to the victim. Ironically, the doctor was found treating the man he hit on the roadside. As a result, the story flow was altered and was in contrast to the prearranged situation set by the researcher. Nonetheless, in the post-test, all nine students were able to follow the cues provided to them in the key cards according to the situation, setting and roles. In fact, every student maintained their roles from the beginning until the end of the role-play. There were apparently events in the students' role plays in which a social service worker met some elderlies in an old folks' home, and they conversed and talked about the lives of those elderlies, and were later observed taking effort to cheer up the elderly residents. Thus, it is clear here that the students could follow all the cues provided to them in the key cards before conducting the role plays. 
S3: I see both of you have a little energy, can we play a game?

S6: sure. [S4: sure]

S3: mmm are you sure you have enough energy [S4: yes, I have enough energy] is the oxygen enough?

S4: I can, I can, I can.

S3: I have many game [SIC] surely, but according to your condition and the doctor's prescription, you are only allowed to do "Double-This Double- That". What is that?

The ability to follow the cues provided in the key cards is further supported when in the questionnaire, $100 \%$ of the students (22\% 'Agree' and $78 \%$ 'Strongly Agree') agreed that they could speak better English with the help of the key cards in the role play. The key cards provided to the students before conducting the role play helped in giving the students some ideas on how to create dialogues that would best suit the situation and roles given to them. This highlights the importance of providing key cards for students in a role play as suggested by Kusnierek (2015) in her study of teaching English speaking skills to EFL learners. Kusnierek prepared cue cards before assigning role plays to her students which outlined several instructions to give the students a gist of what they should be saying when performing role play. From the cue cards, the students would be able to expand their ideas and integrate a lot of other things that would best suit the situation and roles set for the role plays.

\subsubsection{Analysis on Students' Contextual Speech}

The following Table 1.4 illustrates the results obtained from the observation checklist during the preand post-test pertaining to student's contextual speech skills.

Table 1.4 Observation checklist on students' speech context

\begin{tabular}{llll}
\hline No. Item & $\begin{array}{l}\text { Pretest } \\
\text { (No. } \\
\text { students) }\end{array}$ & $\begin{array}{l}\text { Post-test } \\
\text { (No. of } \\
\text { students) }\end{array}$ \\
\hline $1 \quad \begin{array}{l}\text { Able to give opinion appropriately } \\
\text { in the role play }\end{array}$ & 3 & 5 \\
2 & $\begin{array}{l}\text { Able to ask question appropriately } \\
\text { in the role play } \\
\text { Able to make suggestion } \\
\text { appropriately in the role play } \\
\text { Able to give advice appropriately } \\
\text { in the role play }\end{array}$ & 5 & 7 \\
Able to get information from other & 3 & 3 \\
\hline $\begin{array}{l}\text { speakers in the role play } \\
\text { Able to provide information } \\
\text { appropriately in the role play }\end{array}$ & 3 & 5 \\
\hline
\end{tabular}


Results obtained from the observation during this study showed that students generally did not have much trouble in adhering to the context of speaking when they spoke and uttered their dialogues while role playing. When they tried to speak according to the context of the speech, they actually managed to do it with little difficulty. When they asked questions, or gave opinion in their dialogues, they were able to choose the proper word and the proper sentence structure when uttering these speeches. The only difference between the pre-test and the post-test is the increment in the number of students who really managed to speak correctly according to the context. Thus, we can say that the students were initially able to realize contextual speech, but the treatment given to them for four weeks managed to provide them with a better awareness of speaking contextually and this is evident as each item in the context skill showed an increment in the number of students who did well for the item. Table 1.5 below are sample extracts of students speaking appropriately according to the speech context in the pre-test as well as the post-test.

Table 1.5 Extracts of appropriate speaking according to the speech context from the students

\begin{tabular}{|c|c|}
\hline Context & Extracts from the students' speech \\
\hline Give opinion & $\begin{array}{l}\text { S6: okay, I think we, we need to bring him to the hospital first and } \\
\text { then we can check with that. we need to lift him }\end{array}$ \\
\hline Ask question & $\begin{array}{l}\text { S4: where are you going? } \\
\text { S3: what happen [SIC] to him? } \\
\text { S1: Calvin, why do you look so sad? }\end{array}$ \\
\hline Make suggestion & $\begin{array}{l}\text { S3: okay okay, in, out, in and <PULLS S2 LEG }>\text { [S2: ughh!] out, } \\
\text { nice, okay. umm, okay, I think the bone just umm in, okay ahh ahh } \\
\text { your leg will be simen [SIC], maybe in } 1 \text { or } 2 \text { months, we will have } \\
\text { this simen [SIC] leg, ah but you have to come to hospital weekly } \\
\text { because we want to see you and tell your bone, clear or not. } \\
\text { understand? }\end{array}$ \\
\hline Give advice & S3: so, my advice, if you play motor, don't ride recklessly (XX) \\
\hline Get information & S6: where else did you feel your pain? \\
\hline $\begin{array}{l}\text { from other } \\
\text { speakers }\end{array}$ & S8: you look so pale. are you okay? have you taken your medicine? \\
\hline $\begin{array}{l}\text { Provide } \\
\text { information }\end{array}$ & $\begin{array}{l}\text { S4: I came here because my, my son and daughter thought that I } \\
\text { was a burden to them as I was sick and they don't [SIC] want to } \\
\text { take care of me anymore and they just drop [SIC] me here. } \\
\text { S3: actually, I'm a social worker. I just volunteer. I'm from UTM. } \\
\text { maybe, maybe I know him. }\end{array}$ \\
\hline
\end{tabular}

\subsubsection{Analysis of Students' Interactive Communication}

Table 1.6 outlines the results of students' interactive communication which was gathered via the observation checklist during the pre- and post-test. 
Table 1.6 Observation checklist on students' interactive communication

\begin{tabular}{llll}
\hline No. Item & $\begin{array}{l}\text { Pretest } \\
\text { (No. of } \\
\text { students) }\end{array}$ & $\begin{array}{l}\text { Post-test } \\
\text { (No. of } \\
\text { students) }\end{array}$ \\
\hline $1 \quad$ & $\begin{array}{l}\text { Able to introduce new ideas into } \\
\text { the conversation in the role play }\end{array}$ & 5 \\
2 & $\begin{array}{l}\text { Able to keep a conversation going } \\
\text { by using questions like "How } \\
\text { about you?" "What do you } \\
\text { think?" } \\
\text { Able to listen and respond to other } \\
\text { speakers appropriately during the } \\
\text { role play }\end{array}$ & 5 \\
\end{tabular}

Item 1 from Table 1.6 shows that five students were able to introduce new ideas into the conversation in the role play in the post-test as compared to only three students in the pre-test. During the pre-test, Student 7, 8 and 9 obviously changed the situation and roles assigned to them when conducting the role play. They did not follow the cues provided in the key cards and carried out a different version of role play instead of the one intended. However, in the post-test, five students could introduce new ideas into the conversation during the post-test role play by following the guides from the key cards without straying away from the topic. In addition, the students were also able to add new but related ideas which were not mentioned in the key cards into their conversational acts. For example, Student 3 reminded the elderlies (Student 4 and 6) of death nearing their life by giving 'kafan cloth' as a present. He softly advised the elderlies to start preparing for the end of their life and to take care of each other until the end.

S3: I have aaa very, this, this gift is very very important for both of you [S4: it's so big] so big, because it can aaa fit two people. you know what is this?

S4: no

S3: because this is aaa my last time vacation for you, this is my appreciation for you. this is aaa 'kafan' cotton <DISPLAYS 'KAFAN'COTTON>

Item 2 shows that five students could keep a conversation going by using questions like "How about you?" "What do you think?" in the post-test as compared to only one student in the pre-test. For instance, Student 4 (the witness) asked the doctor (Student 6) about the condition of his friend who was involved in an accident (Student 5 ) after the Dr asked him how he is related to victim.

\section{S4: how is him Dr?}

The doctor asked the witness how he was related to victim of the accident. He replied by saying the victim was his former classmate who was hit by a car on his way to the night club. After the 
doctor stopped asking, Student 4 kept the conversation going by asking the doctor about the current condition of his friend. Another example is when Student 3 who acted as a social worker asked questions about their past lives to the elderly residents at the old folks' home (Student 4 and 6).

S3: take, take a deep breath, take a deep breath <S6 INHALES> let go, let go, let go. oh uncle! $<$ LOOKS AT S4> [S4: yeah?] why you have oxygen at there? are you a tanker?

We can see from the extract above that Student 3 tried hard to keep the conversation going within his group when he pointed toward Elderly Resident 2 (Student 4) to ask about his oxygen tank right after listening to Elderly Resident 1's (student 6) story of his forgetful son. This is an improvement to his late response during the pre-test as indicated in the following extract.

S3: usually because people had man like you, drive like superman. ahh so, because, anything to speak?

S1: ah no dr, thank you $d r$

S3: <LOOKS AT S1><0:06> ah how about ahh later I call, nurse, you want nurse? [S1: it's okay dr, it's okay dr] uh it's okay ah, today you cannot go home, I want to see whether your leg, ahh ahh is there anyone I can call?

Student 3 (the doctor) adviced Student 1 (the patient) against riding recklessly and asked if he had anything to say. However, Student 1 replied that he had nothing to say, Student 3 kept silent for six seconds before addressing the topic of wanting to call out a nurse for Student 1 which was rather unrelated to the situation they were in. Student 3 was apparently clueless and did not know what to say at that particular point of conversation. However, he improved in the post-test when he tried not to leave a silent gap during conversation throughout his group's role play. Thus, this proves that the 4-week treatment was able to improve students' interactive communication as they were able to keep the conversation going during the role play.

Item 3 shows that all nine students could listen and respond to other speakers appropriately during the role play as compared to only four students in the pre-test. In the pre-test, Student 9 (the doctor) was unable to respond appropriately to Student 8 (the witness) when he was caught hitting the motorcyclist and keeping quiet about it. He responded with an expression "ekkk" instead of responding properly by using complete and appropriate sentence.

S8: hey, I know you

S9: you don't

S8: yes, I know you

S9: no, you don't

S8: you hit this man

S9: no, I didn't

S8: yes, you are. I have the video

S9: ekkk <COVERS MOUTH WITH PAPER> 
It is obvious that Student 9 was clueless and did not know how to respond to Student 8 (the witness). He did not know how to respond to Student 8 during that particular point of conversation. Consequently, he blurted out the expression "ekkk" while covering his mouth with a paper he was holding in his hand - an instinctive response. In contrast, all the nine students could listen and respond appropriately during the role play as they managed to take turns to speak in an organized manner. This positive effect is also evident when in the questionnaire, $100 \%$ of the students $(55 \%$ 'Agree' and 45\% 'Strongly Agree') agreed that they could understand and respond to other people appropriately in the role play. It shows that through role play, the students learn to listen and respond to others to produce meaningful conversation.

\subsubsection{Analysis of the Students' Responses in the Questionnaire}

Data for this study was also gathered via questionnaire and the results obtained are summarised in Table 1.7.

Table 1.7 The overall responses of the students in the questionnaire

\begin{tabular}{|c|c|c|c|c|c|}
\hline No. & Item & $\begin{array}{l}\text { Strongly } \\
\text { Disagree }\end{array}$ & Disagree & Agree & $\begin{array}{l}\text { Strongly } \\
\text { Agree }\end{array}$ \\
\hline 1 & $\begin{array}{l}\text { I like having role play as a classroom } \\
\text { activity. }\end{array}$ & $\begin{array}{l}1 \\
(11 \%)\end{array}$ & $\begin{array}{l}2 \\
(22 \%)\end{array}$ & $\begin{array}{l}2 \\
(22 \%)\end{array}$ & $\begin{array}{l}4 \\
(45 \%)\end{array}$ \\
\hline 2 & $\begin{array}{l}\text { I prefer role play over the traditional } \\
\text { learning in the classroom. }\end{array}$ & $\begin{array}{l}1 \\
(11 \%)\end{array}$ & $\begin{array}{l}1 \\
(11 \%)\end{array}$ & $\begin{array}{l}4 \\
(45 \%)\end{array}$ & $\begin{array}{l}3 \\
33 \%)\end{array}$ \\
\hline 3 & $\begin{array}{l}\text { I am able to speak English confidently } \\
\text { through role play. }\end{array}$ & 0 & $\begin{array}{l}1 \\
(11 \%)\end{array}$ & $\begin{array}{l}6 \\
(67 \%)\end{array}$ & $\begin{array}{l}2 \\
(22 \%)\end{array}$ \\
\hline 4 & $\begin{array}{l}\text { I am able to interact comfortably with } \\
\text { other people in English through role } \\
\text { play. }\end{array}$ & 0 & 0 & $\begin{array}{l}5 \\
(55 \%)\end{array}$ & $\begin{array}{l}4 \\
(45 \%)\end{array}$ \\
\hline 5 & $\begin{array}{l}\text { Role play helps reduce my anxiety in } \\
\text { speaking English in the classroom. }\end{array}$ & $\begin{array}{l}1 \\
(11 \%)\end{array}$ & $\begin{array}{l}1 \\
(11 \%)\end{array}$ & $\begin{array}{l}3 \\
(33 \%)\end{array}$ & $\begin{array}{l}4 \\
(45 \%)\end{array}$ \\
\hline 6 & $\begin{array}{l}\text { I am able to express my ideas clearly } \\
\text { through role play. }\end{array}$ & $\begin{array}{l}1 \\
(11 \%)\end{array}$ & $\begin{array}{l}2 \\
(22 \%)\end{array}$ & $\begin{array}{l}4 \\
(45 \%)\end{array}$ & $\begin{array}{l}2 \\
(22 \%)\end{array}$ \\
\hline 7 & $\begin{array}{l}\text { I am able to understand and respond to } \\
\text { other people appropriately through role } \\
\text { play. }\end{array}$ & 0 & 0 & $\begin{array}{l}5 \\
(55 \%)\end{array}$ & $\begin{array}{l}4 \\
(45 \%)\end{array}$ \\
\hline 8 & $\begin{array}{l}\text { Role play helps improve my English- } \\
\text { speaking skills. }\end{array}$ & 0 & 0 & $\begin{array}{l}6 \\
(67 \%)\end{array}$ & $\begin{array}{l}3 \\
(33 \%)\end{array}$ \\
\hline 9 & $\begin{array}{l}\text { I am able to speak English better with } \\
\text { the help of keycards in a role play. }\end{array}$ & 0 & 0 & $\begin{array}{l}2 \\
(22 \%)\end{array}$ & $\begin{array}{l}7 \\
(78 \%)\end{array}$ \\
\hline 10 & $\begin{array}{l}\text { I see improvement in my daily } \\
\text { communication from the practice in } \\
\text { role play. }\end{array}$ & $\begin{array}{l}1 \\
(11 \%)\end{array}$ & $\begin{array}{l}1 \\
(11 \%)\end{array}$ & $\begin{array}{l}4 \\
(45 \%)\end{array}$ & $\begin{array}{l}3 \\
(33 \%)\end{array}$ \\
\hline
\end{tabular}


As shown in Table 1.7, it was found that the majority of the students perceived role play activities as having a positive impact on their speaking skills. Even though some reported contrasting effect, the majority reported the positive impact of role play in the students' English-speaking skills. Items in the questionnaire distributed in this study also gathered information regarding the effects of role-play on speaking skills which is summarised in Table 1.8.

Table 1.8 Questionnaire findings on the effects of role play on speaking skills

\begin{tabular}{|c|c|c|c|c|c|}
\hline No. & Item & $\begin{array}{l}\text { Strongly } \\
\text { Disagree }\end{array}$ & Disagree & Agree & $\begin{array}{c}\text { Strongly } \\
\text { Agree }\end{array}$ \\
\hline 4. & $\begin{array}{l}\text { I am able to interact comfortably with } \\
\text { other people in English through role } \\
\text { play. }\end{array}$ & 0 & 0 & $\begin{array}{c}5 \\
(55 \%)\end{array}$ & $\begin{array}{c}4 \\
(45 \%)\end{array}$ \\
\hline 7. & $\begin{array}{c}\text { I am able to understand and respond to } \\
\text { other people appropriately through role } \\
\text { play. }\end{array}$ & 0 & 0 & $\begin{array}{c}5 \\
(55 \%)\end{array}$ & $\begin{array}{c}4 \\
(45 \%)\end{array}$ \\
\hline 8. & $\begin{array}{l}\text { Role play helps improve my English- } \\
\text { speaking skills. }\end{array}$ & 0 & 0 & $\begin{array}{c}6 \\
(67 \%)\end{array}$ & $\begin{array}{c}3 \\
(33 \%)\end{array}$ \\
\hline 9. & $\begin{array}{l}\text { I am able to speak English better with } \\
\text { the help of key cards in a role play. }\end{array}$ & 0 & 0 & $\begin{array}{c}2 \\
(22 \%)\end{array}$ & $\begin{array}{c}7 \\
(78 \%)\end{array}$ \\
\hline
\end{tabular}

Table 1.8 shows noteworthy results on how the students perceive role play as affecting their speaking skills since there is a major difference between both categories of Disagree (Strongly Disagree and Disagree) and Agree (Strongly Agree and Agree) with the ratio of 0:9 for each of the respective two main categories (Disagree and Agree). In general, for each of these four items, all the students agreed on the positive effect of role play toward their speaking skills while none of them disagreed, which is distinguishable from the other six items in the questionnaire.

\subsection{SUMMARY OF FINDINGS}

From the results of both the observation checklist and questionnaire, the findings indicate that role play both affected and improved students' speaking skills, especially in terms of fluency, comprehension, context and interactive ability. Based on the results obtained from the observation checklist, there is an overall good achievement in students' speaking skills in the post-test role play compared to the pre-test role play, and the improvement ranges from 4 to 6 respondents during the post-test, and therefore showing that speaking skills are improved through role play (Ayuningtias $e t$ al, 2019). 
The questionnaire is the second instrument used in this study to investigate how the students perceive the effects of role play on their speaking skills. Based on the findings, it can be deduced that the students have positive reactions toward role play and most of the respondents agreed (Strongly Agree and Agree) to these items in the questionnaire. Four of the questionnaire's items, (Item 4, Item 7, Item 8 and Item 9) asked if the respondents perceived improvements in their speaking skills after the role-play sessions. All of the respondents agreed while none of them disagreed (Strongly Disagree and Disagree) with these statements. Thus, this further validates the findings gathered in the observation checklist that the respondents also share similar toward role play in affecting and improving their speaking skills.

\subsection{CONCLUSION}

Overall, this study focused on the effects of role play on the students' English-speaking skills. The study showed that role play does improve speaking skills in terms of fluency, comprehension, context and interactive communication among students. The findings also showed and supported Aristy et al. (2019) that role plays offer the potential for the development of knowledge of and about the target language, while fostering confidence in the students.

\section{REFERENCES}

Aristy, I. et al. 2019. Using Three-step Interview to Improve Students' Speaking Ability. Project. 2(2): 74-79.

Ayuningtias, D. A. et al. 2019. The Use of Role-play to Improve Students' Speaking Skill. Project. 2(3): 416-420.

Basurto Santos, N. M., Hernandez Alarcon, M. M. and Pablo, I. M. 2016. Fillers and the Development of Oral Strategic Competence in Foreign Language Learning. Porta Linguarum. 25: 191-201.

Bygate, M. 1987. Speaking. Oxford: Oxford University Press.

Chaney, A. L. 1998. Teaching Oral Communication in Grades K-8. Boston: Allyn and Bacon.

Christine, P. 2004. Practitioner Research and Evaluation Skills Training in Openand Distance Learning. Commonwealth of Learning.

Chen-jun, W. 2006. Designing Communicative Tasks for College English Courses. Chongqing Normal University and Yangtze Normal University: China

Doughty, C. and Pica, T 1986. 'Information Gap' Tasks: Do They Facilitate Second Language Acquisition? TESOL Quarterly. 20/2: 305-25

De Wilde, V., Brysbaert, M., Eyckmans, J. 2020. Learning English through Out-of-school Exposure. which Levels of Language Proficiency are Attained and which Types of Input are Important? Bilingualism-Language and Cognition. 23(1): 171-185. 
Hall, G. E., Quinn, L. F., and Gollnick, D. M. 2008. The Joy of Teaching: Making a Difference in Student Learning. Boston, MA: Allyn and Bacon.

Kusnierek, A. 2015. Developing Students' Speaking Skill through Role Play. World Scientific News.

Lucky Rahayu Nurjamin, Asep Nurjamin, Rima Melati. 2020. What EFL Learners Say in Managing

Their Speech During Academic Presentations. Advances in Social Science, Education and

Humanities Research. Proceedings of the Twelfth Conference on Applied Linguistics (CONAPLIN 2019). https://doi.org/10.2991/assehr.k.200406.023.

Maxwell, C. 1997. Role Play and Foreign Language Learning. Paper Presented at the Annual Meeting of the Japan Association of Language Teachers, Hamamatsu, Japan.

Ments, V. M. 1999. The Effective Use of Role-play: Practical Techniques for Improving Learning. 2nd ed.

Porter-Ladousse, Gillian. 1987. Role Play. Oxford: Oxford University Press.

Rao, Parapulli. 2019. The Importance of Speaking English in English Classrooms. Alford Council of International English and Literature Journal (ACIELJ). 2(2). VS Publication

Rayhan, J., M. 2014. The Impact of Using Role Play Techniques on Improving Pupils' Speaking Skill for Primary School. Majallat Kuliyyah at-Tarbiyyah al-Asasiyyah. 15: 516-530.

Richards, J. C. and Rodgers, T. S. 2001. Approaches and Methods in Language Teaching. 2nd Ed. Cambridge: Cambridge University Press.

Scrivener, J. 2005. Learning Teaching. Oxford: Macmillan Publishers Ltd.

Seliger, H. W. 1977. Does Practice Make Perfect?: A Study of Interaction Patterns and L2 Competence. Language Learning. 27(2): 263-278.

Sumpana, S. 2010. Improving the Students' Speaking Skill by Role Play (A Classroom Action Research on the Eleventh Grade Students of Immersion Program 1 of the State Senior High School of Karangpandan Academic Year 2009/2010). Universitas Muhammadiyah Surakarta.

Yahaya, A., Yahaya, N. and Ismail, S. 2011. Factors contributing to proficiency in English as a Second Language among Chinese Students in Johor Bahru. Elixir Psychology. 41. 